\title{
Influence of protein concentration and coagulation temperature on rennet-induced gelation characteristics and curd microstructure
}

\author{
Ram R. Panthi, ${ }^{1,2,3}$ Alan L. Kelly, ${ }^{2}$ Jeremiah J. Sheehan, ${ }^{1 *}$ Kanak Bulbul, ${ }^{3}$ Almut H. Vollmer, ${ }^{3}$ \\ and Donald J. McMahon ${ }^{3}$ \\ ${ }^{1}$ Teagasc Food Research Centre, Moorepark, Fermoy, Co. Cork, Ireland P61C966 \\ ${ }^{2}$ School of Food and Nutritional Sciences, University College Cork, Cork, Ireland T12YN60 \\ ${ }^{3}$ Western Dairy Center, Department of Nutrition, Dietetics, and Food Sciences, Utah State University, Logan 84321
}

\section{ABSTRACT}

This study characterized the coagulation properties and defined the cutting window $(\mathrm{CW}$; time between storage modulus values of 35 and $70 \mathrm{~Pa}$ ) using rheometry for milk standardized to 4,5 , or $6 \%$ protein and set at 28,32 , or $36^{\circ} \mathrm{C}$. Milks were standardized to a protein-to-fat ratio of approximately 1 by blending ultrafiltration retentate, skim milk, and whole milk. The internal curd microstructure for selected curd samples was analyzed with transmission electron microscopy and scanning electron microscopy. Lowering the coagulation temperature caused longer rennet coagulation time and time to reach storage modulus of $35 \mathrm{~Pa}$, translating into a wider $\mathrm{CW}$. It also led to a lower maximum curd-firming rate (MCFR) with lower firmness at $40 \mathrm{~min}$ at a given protein level. Increasing protein levels resulted in the opposite effect, although without an effect on rennet coagulation time at a given temperature. On coagulation at $28^{\circ} \mathrm{C}$, milk with $5 \%$ protein resulted in a similar MCFR $(\sim 4 \mathrm{~Pa} / \mathrm{min})$ and CW ( 8.25 min) compared with milk with $4 \%$ protein at $32^{\circ} \mathrm{C}$, which reflects more standard conditions, whereas increasing milk to $6 \%$ protein resulted in more than doubling of the curd-firming rate $(\mathrm{MCFR}=9.20$ $\mathrm{Pa} / \mathrm{min}$ ) and a shorter $\mathrm{CW}(4.60 \mathrm{~min})$. Gels set at $28^{\circ} \mathrm{C}$ had lower levels of rearrangement of protein network after 40 min compared with those set at $36^{\circ} \mathrm{C}$. Protein levels, on the other hand, had no influence on the levels of protein network rearrangement, as indicated by loss tangent values. The internal structure of curd particles, as investigated by both scanning electron microscopy and transmission electron microscopy, appeared to have less cross-linking and smaller casein aggregates when coagulated at $28^{\circ} \mathrm{C}$ compared with $36^{\circ} \mathrm{C}$, whereas varying protein levels did not show a marked effect on ag-

Received May 10, 2018.

Accepted September 17, 2018.

*Corresponding author: Diarmuid.sheehan@teagasc.ie gregate formation. Overall, this study showed a marked interactive effect between coagulation temperature and protein standardization of milk on coagulation properties, which subsequently requires adjustment of the CW during cheesemaking. Lowering of the coagulation temperature greatly altered the curd microstructure, with a tendency for less syneresis during cutting. Further research is required to quantify the changes in syneresis and in fat and protein losses to whey due to changes in the microstructure of curd particles arising from the different coagulation conditions applied to the protein-fortified milk.

Key words: ultrafiltration, protein standardization, coagulation property, curd microstructure

\section{INTRODUCTION}

In milk standardization for conventional cheesemaking practice, the protein level of milk is not altered, but the fat level is adjusted to achieve a specific protein-tofat ratio (PFR) based on the type of cheese produced and on desired fat-on-DM content. Concentrating milk using UF offers an opportunity to increase protein levels with several benefits to the cheese industry - for example, reducing the effect of seasonal variation of milk composition in cheesemaking (Broome et al., 1998), increasing process efficiency and cheese yield, and ameliorating issues with poorly coagulating milk (Guinee et al., 1994, 1996a, 2006; Mistry and Maubois, 2017). Use of UF has been broadly categorized based on the extent of protein concentration from low concentration ratios $(\mathbf{L C R} ; 1.2-2 \times)$ to medium concentration ratios $(2-6 \times)$ or high concentration ratios (6-8×; Pouliot, 2008). Protein levels in cheese milk can be increased directly using UF or by supplementing milk with UF retentate (Govindasamy-Lucey et al., 2011) or through supplementation by reconstitution of casein powders into milk (Guinee et al., 2006), depending on legal regulations in various countries. Using LCR UF is the most frequent method for protein concentration, whereas applying 
Table 1. Cheese varieties produced from milk concentrated by UF

\begin{tabular}{|c|c|c|c|c|c|}
\hline Variety & $\begin{array}{c}\text { Maximum protein } \\
\text { level }(\%)\end{array}$ & $\begin{array}{l}\text { Protein-to-fat } \\
\text { ratio }\end{array}$ & TS (\%) & Country $^{1}$ & Reference \\
\hline Cheddar & 4.6 & $0.86-1$ & - & Ireland & Guinee et al., 1996a \\
\hline Cheddar & 4.8 & 0.73 & 17.2 & United States & Ozturk et al., 2015 \\
\hline Cheddar & 5.93 & 0.88 & 18.2 & United States & Oommen et al., 2000 \\
\hline Cheddar & 6 & 0.93 & 17.5 & United States & Acharya and Mistry, 2004 \\
\hline Cheddar & 6 & 0.84 & - & Australia & Ong et al., 2013 \\
\hline Mozzarella & 4 & 1 & 13.5 & Italy & Francolino et al., 2010 \\
\hline Parmesan & 5 & 1.4 & 14.2 & United States & Govindasamy-Lucey et al., 2004 \\
\hline Pizza cheese & 5.85 & 1.31 & 15.2 & United States & Govindasamy-Lucey et al., 2005 \\
\hline Swiss & 4.15 & 1.1 & 13.4 & United States & Govindasamy-Lucey et al., 2011 \\
\hline
\end{tabular}

${ }^{1}$ Country where the studies were performed.

higher concentration ratios adds greater complexity to the process (e.g., rennet coagulation properties) and to the equipment required ( $\mathrm{Lu}$ et al., 2016; Mistry and Maubois, 2017). A summary of studies using LCR UF for different cheese varieties with maximum protein levels, PFR, and TS content is presented in Table 1. It is evident from the studies reviewed that composition of milk (protein level) greatly influences subsequent steps in the cheesemaking process, with the most critical one being rennet coagulation.

In renneted milk systems, individual casein micelles flocculate after loss of the hydrophilic domain from $\kappa$-casein, leading to the formation of casein aggregates and eventually a 3-dimensional protein network, the gel or coagulum (Horne and Banks, 2004; Muñoz et al., 2017). On reaching a suitable firmness, the gel is cut (Govindasamy-Lucey et al., 2011), which then facilitates whey expulsion from the curd. It is well established that increased protein levels (Guinee et al., 2006; Sandra et al., 2011) in milk or higher coagulation temperature (Hussain et al., 2012; Muñoz et al., 2017) increase gel firmness and gel-firming rate (Guinee et al., 1996b; Waungana et al., 1998; Upreti et al., 2011). Guinee et al. (1994) reported that increasing protein to $>5 \%$ caused difficulty in curd cutting using an existing cutting program because of excessive gel strength. Lowering the temperature by 3 to $4^{\circ} \mathrm{C}$ standardizes the coagulation and cutting properties in the case of increased protein concentration (Guinee et al., 1994, 1996a; Govindasamy-Lucey et al., 2011). Similarly, other factors (e.g., $\mathrm{pH}$ and $\mathrm{CaCl}_{2}$ addition) are critically important for the development of the gel (Nájera et al., 2003; Mishra et al., 2005; Muñoz et al., 2017). Thus, improved understanding of the interactive effects of altering coagulation temperature on the rennet coagulation characteristics and curd cutting properties for milk with increased protein content through use of LCR UF is required.
The coagulation properties of a gel are typically characterized by the rheological determination of storage modulus $\left(\mathbf{G}^{\prime}\right)$ and loss modulus $\left(\mathbf{G}^{\prime \prime}\right)$. These parameters facilitate the calculation of rennet coagulation time (RCT), gel firmness at a given time, and gel-firming rate thereafter (Guinee et al., 1996a, b; Sandra et al., 2011). The ratio of $G^{\prime \prime}$ to $G^{\prime}$ gives the value for loss tangent $(\tan \delta)$, which essentially measures the conditions required for breaking of protein-protein bonds of casein aggregates or clusters, leading to the formation of stronger bonds at new junctions (rearrangement) that mostly contribute to increased firmness of the gel (van Vliet et al., 1991; Mellema et al., 2002). This may then create an internal pressure for whey movement, causing endogenous syneresis or microsyneresis. Mellema et al. (2002) demonstrated that rearrangement was facilitated at higher temperature and with lower $\mathrm{pH}$ of the gel, influencing the internal structure of curds.

Structurally, rennet-induced gels entrap fat and whey in the protein network. Ong et al. (2011, 2013) investigated the rheological properties and microstructure of rennet gels at varying set temperatures $(27,30,33$, and $\left.36^{\circ} \mathrm{C}\right)$ and milk protein concentrations $(3.7-5.8 \%)$ in separate studies using scanning electron microscopy and confocal laser scanning microscopy. They reported that gels prepared at $5.8 \%$ protein comprised a dense protein network with fewer pores and unevenly distributed fat globules compared with gels prepared at 3.7 to $4.8 \%$ protein, and that lowering the temperature resulted in a finer network. However, those studies did not investigate the interactive effect of protein content and temperature on rheological and subsequent curd microstructure.

Coagulation temperature in cheesemaking is usually between 20 and $36^{\circ} \mathrm{C}$. For Mozzarella, which is considered a soft cheese, the milk is typically set at 35 to $36^{\circ} \mathrm{C}$, whereas 31 to $32^{\circ} \mathrm{C}$ is common for hard or semihard cheeses. Therefore, an understanding of the 
interactive effects of protein concentration and coagulation temperature on coagulation properties and curd cutting characteristics, as well as resultant curd microstructure and syneresis, is desirable when using protein-fortified milk.

The first objective of this study was to characterize the interactive effects of protein level $(4,5$, and $6 \%)$ and set temperature $\left(28,32\right.$, and $\left.36^{\circ} \mathrm{C}\right)$ on rennet-induced gelation characteristics and on the cutting properties of gels formed. The second objective was to characterize the microstructure of the resultant curd as influenced by those changes in set temperature and protein concentration.

\section{MATERIALS AND METHODS}

\section{Milk Collection and UF}

Bovine milk (fat $3.2 \%$; protein $3.12 \%$ ) was sourced from the George B. Caine Dairy Research and Teaching Center (Wellsville, UT) and transported to the Gary Haight Richardson Dairy Products Laboratory at Utah State University (Logan). After pasteurization $\left(73^{\circ} \mathrm{C}\right.$ for $15 \mathrm{~s})$, UF of whole milk ( $180 \mathrm{~kg}$ ) was carried out at approximately $45^{\circ} \mathrm{C}$ to achieve approximately $3 \times$ concentration using a plant with spiral-wound polyethersulfone membranes with a $10-\mathrm{kD}$ molecular weight cut-off (model ST-2-3838, $10 \mathrm{~cm} \times 100 \mathrm{~cm}$ with a 0.76-mm spacer, $7-\mathrm{m}^{2}$ surface area; Synder Filtration, Vacaville, CA). Retentate and permeate were cooled and stored at approximately $5^{\circ} \mathrm{C}$. Skim milk $(\sim 4 \mathrm{~kg})$ was obtained from a local grocery shop in Logan, Utah.

\section{Milk Standardization and Preparation}

Milk was standardized to protein levels of 4,5 , and $6 \%$ while maintaining a PFR of approximately 1.0 by combining skim milk, whole milk, and retentate. The PFR was chosen to represent cheese varieties that contain $45 \%$ fat in DM. The $\mathrm{pH}$ of milk was 6.63 to 6.78 at approximately $8^{\circ} \mathrm{C}$, and this was adjusted to 6.5 with lactic acid (1:8 dilution, vol/vol). Milk was then heated to $45^{\circ} \mathrm{C}$, cooled to the required coagulation temperature, and divided into 450-g portions before rennet addition. The heating and cooling profile of milk used was performed to minimize the effect of cold storage on rennet coagulation properties (Qvist, 1979; Maciel et al., 2015).

\section{Rheological Properties}

Viscoelastic properties of milk gels were measured using a rheometer (AR-G2, TA Instruments, New Castle, DE) with cup-and-bob geometry as described by San- dra et al. (2011). Oscillation frequency was set to $1 \mathrm{~Hz}$ with strain $2 \%$ in time sweep mode. The gap was set at $5.92 \mathrm{~mm}$. Temperature was controlled and adjusted using the water bath system attached to the rheometer. Low-amplitude oscillation conditions were within the linear viscoelastic region of milk gels (Guinee et al., 1996b).

Double-strength $[\sim 650$ international milk-clotting units (IMCU)/mL] chymosin (Maxiren; DSM Food Specialties USA Inc., Eagleville, PA) was used for milk coagulation. A chymosin solution $(2.6 \mathrm{~mL})$ of a $1: 100$ (vol/vol) dilution was added to $450 \mathrm{~mL}$ of milk, resulting in a standardized addition rate of $37 \mathrm{IMCU} / \mathrm{kg}$. The milk was stirred for $1 \mathrm{~min}$, and then a $20-\mathrm{mL}$ sample was transferred to the rheometer operated at the required set temperature $\left(28,32\right.$, or $36^{\circ} \mathrm{C}$, respectively). Changes in $\mathrm{G}^{\prime}$ and $\mathrm{G}^{\prime \prime}$ were continuously recorded every $30 \mathrm{~s}$ between 42 and $71 \mathrm{~min}$, depending on the rate of gel formation.

Starting time was defined as the point of addition of chymosin. Rennet coagulation time was defined as the time required for the first consistent increase in $\mathrm{G}^{\prime}$ values. Storage modulus data were recorded at 1.5 and 2 times RCT $\left(\mathbf{G}^{\prime}{ }_{1.5}\right.$ and $\mathbf{G}^{\prime}{ }_{\mathbf{2}}$, respectively). Curdfirming rate $\left(\Delta \mathbf{G}^{\prime} / \Delta \mathbf{t}\right)$ was calculated from the change in $\mathrm{G}^{\prime}$ values per minute. Maximum curd-firming rate (MCFR) was the maximum slope of the $\mathrm{G}^{\prime}$ curve as a function of time. Storage modulus at $40 \mathrm{~min}$ after rennet addition $\left(\mathbf{A}_{40}\right)$ and $\tan \delta$ at the same time $\left(\tan \boldsymbol{\delta}_{40}\right)$ were recorded. Time taken to reach $\mathrm{G}^{\prime}$ of $35 \mathrm{~Pa}\left(\mathbf{K}_{35}\right)$ and $70 \mathrm{~Pa}\left(\mathbf{K}_{\mathbf{7 0}}\right)$ was also recorded and was used to calculate the cutting window $(\mathbf{C W})$, or the time thought appropriate for cutting of curd during cheesemaking.

\section{Compositional Analysis of Milk}

Gross composition was determined by Fourier-transform infrared spectroscopy using a Bentley Instruments Dairy Spec FT (Bentley Instruments Inc., Chaska, MN) for raw milk, standardized milk, and UF permeate and retentate. Calcium and phosphorus contents of milk were determined by inductively coupled plasma optical emission spectrometry (Thermo iCAP 6300, Thermo Fisher Scientific, Waltham, MA) using digested milk samples as described by Gavlak et al. (2005). Phosphate was calculated as phosphorus content $\times 3.065$.

\section{Preparation of Coagula for Microstructure Analysis}

Milk (14 kg) was standardized in cheese vats as described above. Combinations of protein content and set temperature of $6 \%$ and $28^{\circ} \mathrm{C}, 4 \%$ and $36^{\circ} \mathrm{C}$ and, $6 \%$ and $36^{\circ} \mathrm{C}$ were chosen to show the largest difference in the curd microstructure. Gels were cut at approximately 35 
Pa using knives with $6 \mathrm{~mm}$ between cutting wires, followed by $4 \mathrm{~min}$ of healing and $1 \mathrm{~min}$ of gentle stirring. Five minutes after cutting, 10 to 15 curd particles per treatment were collected from the stainless steel vat with a spatula and directly transferred to glass vials with primary fixative (formaldehyde/glutaraldehyde $2.5 \%$ each in $0.1 M$ sodium cacodylate buffer, $\mathrm{pH} 7.4$; Electron Microscopy Sciences, Hatfield, PA), taking care not to deform the particles. Particles were stored in primary fixative at $4^{\circ} \mathrm{C}$ overnight. The moisture content of the curd samples was determined in triplicate using a gravimetric (hot-air oven) method.

For transmission electron microscopy (TEM), curd particles were first cut into 1-mm-thick slices, from which small rectangles $(3 \times 1 \times 1 \mathrm{~mm})$ were cut perpendicularly to the skin. Samples were processed at the University of Utah (Salt Lake City) as described by Lu et al. (2015). Briefly, samples were rinsed twice with sodium cacodylate buffer followed by postfixation in osmium tetroxide ( $2 \%$ in distilled $\mathrm{H}_{2} \mathrm{O}$ ) for $1 \mathrm{~h}$ at room temperature and received 2 more rinses with deionized water. Samples were dehydrated in an ascending ethanol series and transitioned to $100 \%$ acetone, gradually infiltrated with resin, embedded in flat-embedding molds, and cured overnight at $70^{\circ} \mathrm{C}$. Thick sections $(\sim 0.5 \mu \mathrm{m})$ were cut and stained for light microscopy followed by thin sectioning $(70-100 \mathrm{~nm})$ using an ultramicrotome (Leica Microsystems Inc., Buffalo Grove, IL). Thin sections were contrasted with salts of uranyl acetate and lead citrate for 10 and 5 min, respectively. Sections were observed with a JEM 1400 Plus TEM (Jeol USA Inc., Peabody, MA) operated at $120 \mathrm{kV}$, and digital images were taken with a Gatan camera (Gatan Inc., Pleasanton, CA).

For scanning electron microscopy, intact curd particles were postfixed and dehydrated as described above. After the last dehydration step in $100 \%$ ethanol, curd particles were frozen in liquid nitrogen and fractured before returning to $100 \%$ ethanol. The ethanol was replaced by hexamethyldisilazane followed by complete dehydration on filter paper. Dried samples were mounted onto aluminum stubs with double-sticky carbon tape and coated with approximately $15 \mathrm{~nm}$ of gold/ palladium using a sputter coater (Gatan 682 Precision Etching and Coating System; Gatan Inc.). Samples were viewed and imaged in an environmental scanning electron microscopy (Quanta 600 FEG, FEI, Hillsboro, OR) at low vacuum (0.08-0.23 torr) and with an accelerating voltage of $15 \mathrm{kV}$.

\section{Experimental Design and Statistical Analysis}

A split-plot factorial experimental design was used with protein concentration in the main plot and coagu- lation temperature in the subplot. The experimental design focused on studying viscoelastic properties of renneted milk standardized at 4,5 , or $6 \%$ protein level (PFR $\sim 1.0)$ at different set temperatures $(28,32$, or $36^{\circ} \mathrm{C}$ ). Each treatment was performed in duplicate. Milk composition and viscoelastic parameters were compared using the PROC GLM function in SAS (version 9.4, SAS Institute Inc., Cary, NC), with Tukey adjustment for multiple comparisons of mean differences $(\alpha=0.05)$.

\section{RESULTS AND DISCUSSION}

\section{Milk Composition}

Milks were standardized to protein levels of 4,5 , or $6 \%$ by blending different proportions of whole milk, UF retentate, and skim milk, respectively, while maintaining a PFR of approximately 1.0. As expected, levels of protein, fat, TS, SNF, total calcium, and phosphate increased significantly $(P<0.05)$ with increasing protein content, without a significant change in lactose and PFR levels (Table 2). The relative proportion of individual casein components in each standardized milk was presumed to be similar, as reported by Liu et al. (2014), because UF of whole milk was carried out with a 10 -kDa membrane at $50^{\circ} \mathrm{C}$, minimizing the dissociation of micellar casein components. The ratio of calcium to protein was significantly lower at higher protein levels (6\%) compared with 4 or $5 \%$ protein. During UF, a portion of the soluble calcium partitions with the permeate, whereas the calcium concentration in the milk serum phase remains constant (Salvatore et al., 2011; Sandra et al., 2011). Hence, as protein (and fat) concentration is increased, there is a lower volume fraction of the milk serum phase, and the total calcium level in the concentrate decreases. Therefore, even though the overall calcium-to-protein ratio is lower, calcium-to-protein ratio within the casein micelles was not expected to change. A similar PFR in standardized milk samples indicated that, with increasing protein levels, fat levels also increased. A PFR of approximately 1 was selected in this study to represent semihard cheese types of $45 \%$ fat in DM. Milk standardized in the present study was concentrated approximately 1.25- to 1.9-fold, reflecting LCR UF (Mistry and Maubois, 2017).

\section{Rheological Properties of Milk Gels as Influenced by Protein Standardization and Coagulation Temperature}

The development of $\mathrm{G}^{\prime}$ as a function of time in milk samples with different protein levels $(4,5$, and $6 \%)$ at different set temperatures $\left(28,32\right.$, and $\left.36^{\circ} \mathrm{C}\right)$ is shown 
Table 2. Composition of the standardized milks used in this study

\begin{tabular}{lccc}
\hline & \multicolumn{3}{c}{ Standardized milk } \\
\cline { 2 - 4 } Component & $4 \%$ Protein & $5 \%$ Protein & $6 \%$ Protein \\
\hline Protein $(\mathrm{g} / 100 \mathrm{~g})$ & $3.99^{\mathrm{c}}$ & $4.96^{\mathrm{b}}$ & $5.96^{\mathrm{a}}$ \\
Fat $(\mathrm{g} / 100 \mathrm{~g})$ & $3.87^{\mathrm{c}}$ & $4.85^{\mathrm{b}}$ & $5.89^{\mathrm{a}}$ \\
Protein-to-fat ratio & $1.03^{\mathrm{a}}$ & $1.02^{\mathrm{a}}$ & $1.01^{\mathrm{a}}$ \\
Lactose $(\mathrm{g} / 100 \mathrm{~g})$ & $4.83^{\mathrm{a}}$ & $4.80^{\mathrm{a}}$ & $4.84^{\mathrm{a}}$ \\
SNF $(\mathrm{g} / 100 \mathrm{~g})$ & $9.75^{\mathrm{c}}$ & $10.77^{\mathrm{b}}$ & $11.88^{\mathrm{a}}$ \\
Calcium $(\mathrm{g} / \mathrm{kg})$ & $1.30^{\mathrm{c}}$ & $1.60^{\mathrm{b}}$ & $1.87^{\mathrm{a}}$ \\
Phosphate $(\mathrm{g} / \mathrm{kg})$ & $3.21^{\mathrm{c}}$ & $3.83^{\mathrm{b}}$ & $4.35^{\mathrm{a}}$ \\
Calcium-to-protein ratio $(\mathrm{mg} / \mathrm{g})$ & $32.54^{\mathrm{a}}$ & $32.35^{\mathrm{a}}$ & $31.31^{\mathrm{b}}$ \\
TS $(\mathrm{g} / 100 \mathrm{~g})$ & $13.64^{\mathrm{c}}$ & $15.63^{\mathrm{b}}$ & $17.77^{\mathrm{a}}$ \\
\hline
\end{tabular}

${ }^{\mathrm{a}-\mathrm{c}}$ Means within a row with the same superscripts were not significantly different $(\alpha=0.05)$. Data presented are the mean of 6 measurements from duplicate trials.

${ }^{1}$ Calculated as $\mathrm{PO}_{4}$ (phosphorus content $\times 3.065$ ).

in Figure 1. Gels showed higher $\mathrm{G}^{\prime}$ values at a given time with increasing protein levels, and, with increasing set temperature, the $\mathrm{G}^{\prime}$ further increased (Figure $1 \mathrm{~A}, \mathrm{~B}$, and $\mathrm{C}$ ) as did $\Delta \mathrm{G}^{\prime} / \Delta \mathrm{t}$ (Figure 2). The latter graphically represents the slope of the gel formation curves $\left(\mathrm{G}^{\prime}\right)$ as shown in Figure 1. After the RCT is reached, $\Delta \mathrm{G}^{\prime} / \Delta \mathrm{t}$ increased to a maximum value and then decreased. With increasing protein levels there was an increase in $\Delta \mathrm{G}^{\prime} / \Delta \mathrm{t}$, and with increasing set temperature a large increase in $\Delta \mathrm{G}^{\prime} / \Delta \mathrm{t}$ was observed (Figure $2 \mathrm{~A}, \mathrm{~B}, \mathrm{C}$ ). The increase of $\Delta \mathrm{G}^{\prime} / \Delta \mathrm{t}$ with respect to higher temperature and protein concentration indicates increased frequency of collisions between the casein micelles at higher protein levels, and this perhaps led to the formation of a stronger protein network, as indicated by the faster $\mathrm{G}^{\prime}$ development at a given time (Sandra et al., 2011). The rheological properties of such gels (discussed below) at a given time were calculated, and the interactive effects on gel characteristics are illustrated in Supplemental Figure S1 (https://doi.org/ 10.3168/jds.2018-15039).

$R C T$. A significant influence of coagulation temperature on RCT, which decreased with increasing temperature, was observed, whereas protein concentration had no significant influence, nor was there any significant interaction between temperature and protein levels (Table 3). Values of RCT are shown in Table 4. The definition of RCT varies and has included the time when G' equals G" (Karlsson et al., 2007; Salvatore et al., 2011; Lu et al., 2017), the time when there is a consistent increase in viscosity (Nájera et al., 2003), and the time when $\mathrm{G}^{\prime}$ value is above a fixed value, such as $0.2 \mathrm{~Pa}$ (Guinee et al., 1996b) or $1 \mathrm{~Pa}$ (Waungana et al., 1998; Mishra et al., 2005). We chose to use the time when a consistent increase in $\mathrm{G}^{\prime}$ was first observed, and this occurred between 0.25 and 0.75 $\mathrm{Pa}$. On this basis, RCT decreased as set temperature increased (Supplemental Figure S1, https://doi.org/10
$.3168 /$ jds.2018-15039), probably because of increased hydrophobic interactions and enzymatic activity, which probably led to earlier formation of casein aggregates (Mishra et al., 2005).

Rennet coagulation time was not influenced significantly by increasing protein levels from 4 to $6 \%$ at a given temperature (Table 3), which was consistent with the results of Sandra et al. (2011), who reported no influence of increasing protein concentration on RCT, whereas others (Waungana et al., 1998; Karlsson et al., 2007) reported longer RCT or even shorter RCT (Guinee et al., 2006; Govindasamy-Lucey et al., 2011; Upreti et al., 2011). Such differences may result from differences in the proportion of $\kappa$-casein hydrolysis arising from differences in substrate-to-enzyme ratios (Karlsson et al., 2007; Sandra et al., 2011), differences in methods and definition of RCT, or differences in milk pH (Waungana et al., 1998). We used a constant concentration (37 IMCU $/ \mathrm{kg}$ ) of rennet at all protein levels, which was probably sufficient to hydrolyze $\kappa$-casein to form casein aggregates required for coagulation at protein levels between 4 and $6 \%$ at a given coagulation temperature. Sandra et al. (2011) observed approximately $90 \%$ hydrolysis of $\kappa$-casein in skim milk gels regardless of concentration of protein to approximately $12.1 \%$ when using a similar concentration of rennet $(34 \mathrm{IMCU} / \mathrm{kg})$ at $30^{\circ} \mathrm{C}$.

Development of Gel Firmness. The values for $\mathrm{G}_{1.5}^{\prime}$ were considered to be equivalent to the gel firmness suitable for cutting a coagulum 30 min after rennet addition. During cheesemaking with milk of normal protein concentration, onset of gelation is observed approximately 20 min after renneting. Values of $\mathrm{G}_{2}{ }_{2}$ were considered to represent the curd firmness when most of the $\kappa$-casein is cleaved by chymosin. Whereas $\mathrm{G}_{1.5}^{\prime}$ and $\mathrm{G}_{2}^{\prime}$ are considered independent of RCT, $\mathrm{A}_{40}$ can be considered an expression of the rate at which coagulum formation occurs and is dependent on RCT 

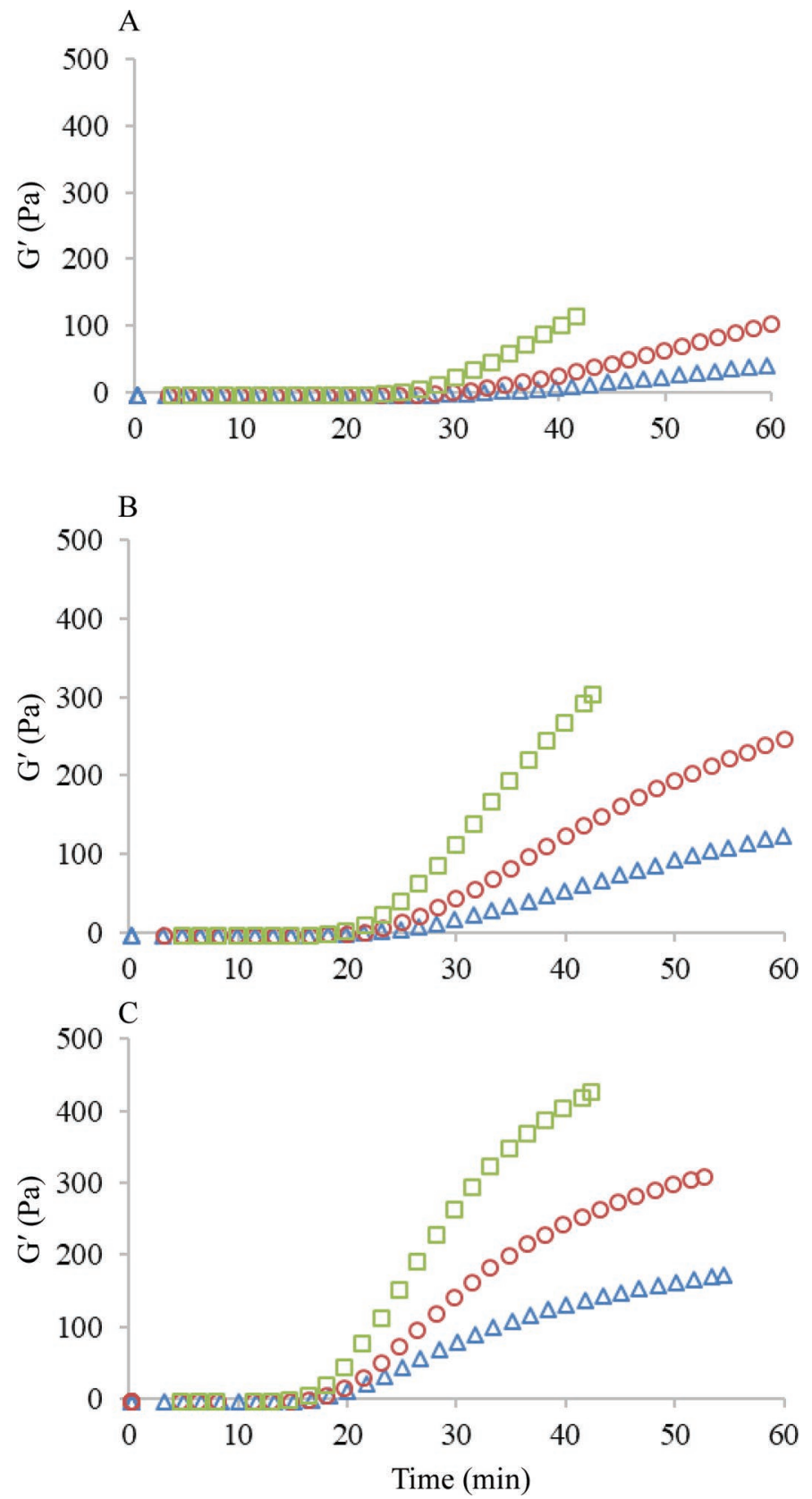

Figure 1. Storage modulus $\left(\mathrm{G}^{\prime}\right)$ of rennet-induced gels from milk standardized using UF retentate and containing $4 \%(\Delta), 5 \%(\mathrm{O})$, or $6 \%(\square)$ protein and set at $28^{\circ} \mathrm{C}(\mathrm{A}), 32^{\circ} \mathrm{C}(\mathrm{B})$, or $36^{\circ} \mathrm{C}(\mathrm{C})$.

(McMahon and Brown, 1982; Lu et al., 2017). The values of $\mathrm{G}_{1.5}^{\prime}, \mathrm{G}_{2}^{\prime}$, and $\mathrm{A}_{40}$ in renneted milk samples at different protein concentrations and set temperatures are shown in Table 4. There was a significant interaction between protein levels and set temperature for $\mathrm{G}^{\prime}{ }_{2}$ $(P<0.05)$ and $\mathrm{A}_{40}(P<0.01)$ but not for $\mathrm{G}_{1.5}^{\prime}$ (Table 3). Curd firmness, represented by $\mathrm{G}_{1.5}^{\prime}, \mathrm{G}_{2}^{\prime}$, and $\mathrm{A}_{40}$, was highly influenced by coagulation temperature and protein concentration (Table 3). This indicates that the gel strength at $\mathrm{G}_{1.5}^{\prime}$ for cutting may not be suitable for protein-standardized milk because $\Delta \mathrm{G}^{\prime} / \Delta \mathrm{t}$ was highly dependent on protein level and temperature.

Log-linear associations of $\mathrm{G}_{1.5}^{\prime}, \mathrm{G}_{2}^{\prime}$, and $\mathrm{A}_{40}$ with protein levels at each coagulation temperature were observed (Supplemental Figure S2, https://doi.org/ 10.3168/jds.2018-15039), indicating that $\mathrm{G}^{\prime}$ increased logarithmically with increasing protein levels, which is consistent with previously published studies (Guinee et al., 1996b; Lu et al., 2017). Compared with milk with $4 \%$ protein renneted at $32^{\circ} \mathrm{C}$, which most closely represents conditions occurring during cheesemaking
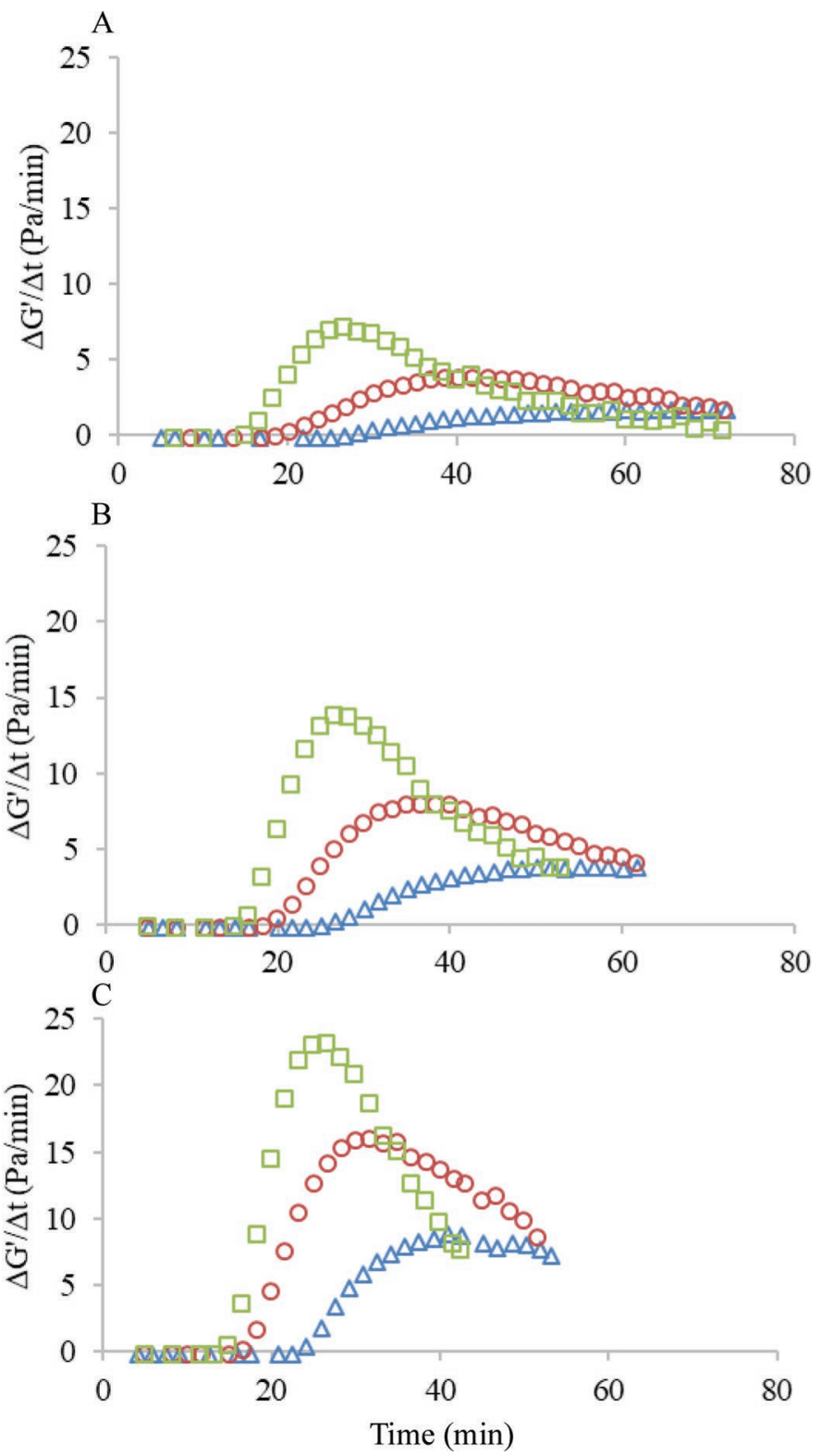

Figure 2. Curd-firming rate $\left(\Delta \mathrm{G}^{\prime} / \Delta \mathrm{t}\right)$ of rennet-induced milk gels from milk standardized using UF retentate and containing $4 \%(\Delta), 5 \%$ $(\bigcirc)$, or $6 \%(\square)$ protein and set at $28^{\circ} \mathrm{C}(\mathrm{A}), 32^{\circ} \mathrm{C}(\mathrm{B})$, and $36^{\circ} \mathrm{C}(\mathrm{C})$. 
Table 3. F-values from ANOVA of gelation properties influenced by milk protein concentration and set temperature

\begin{tabular}{|c|c|c|c|c|c|c|c|c|c|}
\hline Source & $\begin{array}{l}\mathrm{RCT}^{1} \\
(\min )\end{array}$ & $\begin{array}{l}\mathrm{G}_{1.5}^{\prime 2} \\
(\mathrm{~Pa})\end{array}$ & $\begin{array}{l}\mathrm{G}_{2}^{\prime 2} \\
(\mathrm{~Pa})\end{array}$ & $\begin{array}{c}\mathrm{MCFR}^{3} \\
(\mathrm{~Pa} / \mathrm{min})\end{array}$ & $\begin{array}{l}\mathrm{A}_{40}{ }^{4} \\
(\mathrm{~Pa})\end{array}$ & $\operatorname{Tan} \delta_{40}^{4}$ & $\begin{array}{c}\mathrm{k}_{35}^{5} \\
(\mathrm{~min})\end{array}$ & $\begin{array}{l}\mathrm{k}_{70}{ }^{5} \\
(\mathrm{~min})\end{array}$ & $\begin{array}{l}\mathrm{CW}^{6} \\
(\mathrm{~min})\end{array}$ \\
\hline Protein & $1.64^{\mathrm{NS}}$ & $198^{* * *}$ & $372.5^{* * *}$ & $188.5^{* * *}$ & 86.39 *** & $0.12^{\mathrm{NS}}$ & $24.5^{* * *}$ & $47.24^{* * *}$ & $196.8^{* * *}$ \\
\hline
\end{tabular}

${ }^{1} \mathrm{RCT}=$ rennet coagulation time [time at first consistent increase in storage modulus $\left(\mathrm{G}^{\prime}\right)$ ].

${ }^{2} \mathrm{G}^{\prime}$ values at $1.5 \times \operatorname{RCT}\left(\mathrm{G}_{1.5}^{\prime}\right)$ and $2 \times \operatorname{RCT}\left(\mathrm{G}_{2}^{\prime}\right)$.

${ }^{3} \mathrm{MCFR}=$ maximum curd-firming rate based on change in $\mathrm{G}^{\prime}$.

${ }^{4} \mathrm{~A}_{40}$ and $\tan \delta_{40}=$ curd firmness measured as $\mathrm{G}^{\prime}$ and ratio of $\mathrm{G}^{\prime \prime}$ to $\mathrm{G}^{\prime}$, respectively, 40 min after rennet addition.

${ }^{5} \mathrm{k}_{35}$ and $\mathrm{k}_{70}=$ time after addition of rennet to milk during gelation for reaching $\mathrm{G}^{\prime}$ values of 35 and $70 \mathrm{~Pa}$, respectively.

${ }^{6} \mathrm{CW}=$ cutting window in which the curd has a $\mathrm{G}^{\prime}$ between 35 and $70 \mathrm{~Pa}$.

Significant main or interactive effects at ${ }^{*} P<0.05,{ }^{* *} P<0.01$, and ${ }^{* * *} P<0.001$.

when using protein-standardized milks, increasing temperature or protein concentration caused an increase in $\mathrm{G}_{1.5}^{\prime}, \mathrm{G}_{2}^{\prime}$, and $\mathrm{A}_{40}$ (Table 4). In contrast, when milk containing $5 \%$ protein was renneted at $28^{\circ} \mathrm{C}$, the values describing gel formation development were similar to those of milk with $4 \%$ protein renneted at $32^{\circ} \mathrm{C}$.

$M C F R$. The MCFR can be considered a measure of the rate of aggregation of hydrolyzed casein micelles during coagulation, and MCFR increased with increased protein levels and with increasing coagulation temperature (Table 4). There was also a significant interactive effect of protein content and coagulation temperature on MCFR (Table 3). When comparing the MCFR of different conditions of coagulation temperature and protein concentration, gels set at $28^{\circ} \mathrm{C}$ with $5 \%$ protein showed values close to those of standard conditions (Table 4). Increased $\Delta \mathrm{G}^{\prime} / \Delta \mathrm{t}$ at increasing temperature was probably due to increased hydrophobic interactions of casein micelles and protein rearrangement (van Vliet and Walstra, 1994). The hydrophobic domains in casein have a tendency to reduce contact with $\mathrm{H}_{2} \mathrm{O}$ molecules, providing an entropic-related lowering of energy that favors self-association. Because changes in entropy have a temperature coefficient, such self-association increases with temperature, as there is increased mobility of protons as well as a reduction in electrostatic repulsive forces by binding with calcium (Horne, 1998). Increased $\Delta \mathrm{G}^{\prime} / \Delta \mathrm{t}$ at increasing protein contents was probably due to a higher frequency of collisions between casein aggregates, as the mean distance between casein micelles is reduced when the volume fraction of casein in milk increases (Mishra et al., 2005; Sandra et al., 2011).

Lowering the set temperature to $28^{\circ} \mathrm{C}$ for milk with $5 \%$ protein content may counterbalance hydrophobic interactions and frequency of collisions compared with standard coagulation conditions, thus providing similar structural rigidity. Our results showed that develop-

Table 4. Effects of milk protein concentration and set temperature on gelation properties of cheese milk

\begin{tabular}{|c|c|c|c|c|c|c|c|c|c|c|}
\hline $\begin{array}{l}\text { Protein } \\
(\%)\end{array}$ & $\begin{array}{l}\text { Temperature } \\
\left({ }^{\circ} \mathrm{C}\right)\end{array}$ & $\begin{array}{l}\mathrm{RCT}^{1} \\
(\min )\end{array}$ & $\begin{array}{l}\mathrm{G}_{1.5}{ }^{2} \\
(\mathrm{~Pa})\end{array}$ & $\begin{array}{l}\mathrm{G}_{2}^{\prime 2} \\
(\mathrm{~Pa})\end{array}$ & $\begin{array}{c}\mathrm{MCFR}^{3} \\
(\mathrm{~Pa} / \mathrm{min})\end{array}$ & $\begin{array}{l}\mathrm{A}_{40}{ }^{4} \\
(\mathrm{~Pa})\end{array}$ & $\operatorname{Tan} \delta_{40}^{4}$ & $\begin{array}{l}\mathrm{k}_{35}{ }^{5} \\
(\mathrm{~min})\end{array}$ & $\begin{array}{l}\mathrm{k}_{70}{ }^{5} \\
(\mathrm{~min})\end{array}$ & $\begin{array}{l}\mathrm{CW}^{6} \\
(\mathrm{~min})\end{array}$ \\
\hline 4 & 28 & $27.0^{\mathrm{a}}$ & $13.3^{\mathrm{d}}$ & $35^{\mathrm{e}}$ & $1.85^{\mathrm{f}}$ & $12.6^{\mathrm{d}}$ & $0.27^{\mathrm{bc}}$ & $53.9^{\mathrm{a}}$ & $72.9^{\mathrm{a}}$ & $19.04^{\mathrm{a} 7}$ \\
\hline 4 & 32 & $21.5^{\mathrm{ab}}$ & $24.7^{\mathrm{cd}}$ & $69^{\mathrm{e}}$ & $4.27^{\mathrm{def}}$ & $58.7^{\mathrm{cd}}$ & $0.27^{\mathrm{b}}$ & $34.9^{\mathrm{bc}}$ & $43.2^{\mathrm{bc}}$ & $8.25^{\mathrm{b}}$ \\
\hline 5 & 28 & $25.7^{\mathrm{a}}$ & $26.3^{\mathrm{cd}}$ & $74^{\mathrm{d}}$ & $4.01^{\mathrm{ef}}$ & $31.0^{\mathrm{cd}}$ & $0.26^{\mathrm{c}}$ & $41.3^{\mathrm{b}}$ & $50.6^{\mathrm{b}}$ & $9.25^{\mathrm{b}}$ \\
\hline 5 & 32 & $19.5^{\mathrm{ab}}$ & $42.0^{\mathrm{cd}}$ & $119^{\mathrm{c}}$ & $8.35^{\mathrm{cd}}$ & $128^{\mathrm{c}}$ & $0.27^{\mathrm{b}}$ & $28.3^{\text {cde }}$ & $32.9^{\text {cde }}$ & $4.63^{\mathrm{cd}}$ \\
\hline 5 & 36 & $15.4^{\mathrm{b}}$ & $58.4^{\mathrm{b}}$ & $163^{\mathrm{b}}$ & $14.0^{\mathrm{b}}$ & $249^{\mathrm{b}}$ & $0.30^{\mathrm{a}}$ & $21.3^{\mathrm{de}}$ & $24.2^{\mathrm{de}}$ & $2.90^{\mathrm{cd}}$ \\
\hline & SEM & 1.12 & 6.35 & 17.49 & 1.63 & 30.46 & 0.004 & 2.60 & 3.78 & 1.22 \\
\hline
\end{tabular}

\footnotetext{
${ }^{\mathrm{a} f}$ Means within a column with the same superscript were not significantly different $(\alpha=0.05)$.

${ }^{1} \mathrm{RCT}=$ rennet coagulation time [time at first consistent increase in storage modulus $\left(\mathrm{G}^{\prime}\right)$ ].

${ }^{2} \mathrm{G}^{\prime}$ values at $1.5 \times \operatorname{RCT}\left(\mathrm{G}_{1.5}^{\prime}\right)$ and $2 \times \operatorname{RCT}\left(\mathrm{G}_{2}^{\prime}\right)$.

${ }^{3} \mathrm{MCFR}=$ maximum curd-firming rate based on change in $\mathrm{G}^{\prime}$.

${ }^{4} \mathrm{~A}_{40}$ and $\tan \delta_{40}=$ curd firmness measured as $\mathrm{G}^{\prime}$ and ratio of $\mathrm{G}^{\prime \prime}$ to $\mathrm{G}^{\prime}$, respectively, 40 min after rennet addition.

${ }^{5} \mathrm{k}_{35}$ and $\mathrm{k}_{70}=$ time after addition of rennet to milk during gelation for reaching $\mathrm{G}^{\prime}$ values of 35 and $70 \mathrm{~Pa}$, respectively.

${ }^{6} \mathrm{CW}=$ cutting window in which the curd has a $\mathrm{G}^{\prime}$ between 35 and $70 \mathrm{~Pa}$.

${ }^{7}$ Projected value as $\mathrm{G}^{\prime}$ reached only $45.5 \mathrm{~Pa}$ during the $60 \mathrm{~min}$ in which the gel was monitored.
} 
ment of gel firmness for milk up to $5 \%$ protein, which is higher than the levels suggested by Guinee et al. (1994) and Govindasamy-Lucey et al. (2011), can be normalized by lowering the set temperature. However, above $5 \%$ protein, the $\Delta \mathrm{G}^{\prime} / \Delta \mathrm{t}$ was observed to be much higher than standard conditions. In contrast, when milk with $4 \%$ protein was set at $28^{\circ} \mathrm{C}$, it took longer to reach the appropriate firmness $\left(\mathrm{K}_{35}\right.$ and $\left.\mathrm{K}_{70}\right)$ as well as lower $\mathrm{G}_{1.2}^{\prime}, \mathrm{G}_{2}^{\prime}$, and $\mathrm{A}_{40}$ because of slow $\Delta \mathrm{G}^{\prime} / \Delta \mathrm{t}$. Such conditions would have negative effects on commercialscale process efficiency.

\section{Endogenous Syneresis}

Values for $\tan \delta_{40}$ increased significantly $(P<0.001)$ with increasing temperature, whereas protein levels had no significant influence (Table 4); there was also a slight interactive effect $(P<0.05)$ of coagulation temperature and protein levels (Table 3). At higher temperature, greater disruption of weak protein-protein bonds occurs, which results in rearrangement of casein aggregates, and formation of stronger bonds in a new location (van Vliet et al., 1991), and causes a contraction in the gel network. This creates pressure for whey to move internally, causing endogenous syneresis. This suggests that, by increasing coagulation temperature, curds are susceptible to greater syneresis, as indicated by higher values of $\tan \delta_{40}$ compared with gels set at lower temperature (Table 4). This result is consistent with the findings of Mellema et al. (2002) and Mishra et al. (2005), who observed higher tan $\delta$ values of milk gels at increased temperatures. A similar trend for tan $\delta$ values at $28^{\circ} \mathrm{C}$ was also reported by Hussain et al. (2012) at different protein levels for cow and buffalo milks. Furthermore, at increased set temperatures, caseins probably are less voluminous due to increased hydrophobic interactions, presumably leading to binding of caseins more tightly (van Vliet and Walstra, 1994; Horne, 1998), which may result in more reactive sites for fusion, conferring structural flexibility.

We propose that gels prepared at lower temperature have less rearrangement even at higher protein levels, causing a slower development in curd firmness. The lower $\tan \delta$ values also indicate that the curds set at lower temperature had less tendency for outward movement of whey compared with curd set at higher temperature because of less internal rearrangement (Mishra et al., 2005). Although cooking of curds in the later stages of cheesemaking may alter the structure, which favors rearrangement, the effect of having lower $\tan \delta$ values at lower set temperature during coagulation may have a bigger effect on initial whey expulsion during cutting and healing.
Because all milk samples were acidified to $\mathrm{pH} 6.5$ (to minimize batch-to-batch variations in milk $\mathrm{pH}$ ), we hypothesize that lowering set temperature could be combined with lowering the $\mathrm{pH}$ of cheese milk to give a more suitable curd formation when making cheese using LCR UF concentrated milk. At lower $\mathrm{pH}$, network rearrangement is enhanced (Mellema et al., 2002), favoring greater aggregation between casein micelles, which could possibly result in faster release of whey required for initial stirring. However, this again will lead to the faster gel formation at higher $\Delta \mathrm{G}^{\prime} / \Delta \mathrm{t}$, resulting in higher curd firmness.

\section{CW}

In this study, $\mathrm{CW}$ (i.e., time between $\mathrm{K}_{35}$ and $\mathrm{K}_{70}$ ) was $8.25 \mathrm{~min}$ for gels of $4 \%$ protein set at $32^{\circ} \mathrm{C}$. Generally, in cheesemaking, curd is cut within a CW of 7 to 8 min (Guinee et al., 1994), although this depends on the size and type of the cheese vat used. With increased protein levels in milk, $\mathrm{K}_{35}$ and $\mathrm{K}_{70}$ decreased, and this further decreased with increased coagulation temperature (Table 4). There was a significant interactive effect of protein levels and coagulation temperature on $\mathrm{K}_{35}$ and $\mathrm{K}_{70}$ (Table 3 ), suggesting that set-to-cut time during the cheesemaking process is reduced with increasing protein levels at a given temperature. Cutting of gels based on standard operating procedure (where gel is cut based on fixed time of $\sim 30 \mathrm{~min}$ ) while using protein-standardized milk may result in excessive curd firmness because of higher $\Delta \mathrm{G}^{\prime} / \Delta \mathrm{t}$. However, reducing the set temperature to $28^{\circ} \mathrm{C}$ for milk of $5 \%$ protein resulted in $\mathrm{K}_{35}$ values (41.3 min) that were statistically similar $(P=0.53$; Table 4$)$ to those of standard conditions (34.9 $\mathrm{min})$.

Guinee et al. (1994) reported difficulty in cutting curd while using milk with $>4 \%$ protein set at $32^{\circ} \mathrm{C}$, and excessive curd firmness was reported to show subsequent tearing of curds, leading to decreased cheese yield. In the present study, increasing protein levels and increasing set temperature markedly reduced $\mathrm{CW}$ (e.g., to 1.95 min for milk with $6 \%$ protein set at $36^{\circ} \mathrm{C}$; Table 4 ), indicating the need for modification of the cutting program when altering milk composition. A CW of 9.25 min for milk of $5 \%$ protein set at $28^{\circ} \mathrm{C}$ was close to that of the milk with $4 \%$ protein and set at $32^{\circ} \mathrm{C}$, indicating that a similar cutting procedure can be used to cut the gel under these conditions.

Such a reduction in set temperature on increasing protein levels would influence curd $\mathrm{pH}$ development during cheesemaking because of slower starter culture growth as well as increased buffering capacity (Guinee et al., 1996a; Salvatore et al., 2011) of the curd. To 
ameliorate this situation, using higher starter inoculum levels has been suggested (Guinee et al., 2006). Seasonal variation in milk composition in some countries accounts for a large variation in processability of milk (O'Callaghan et al., 2016) for cheesemaking. We propose that protein and $\mathrm{pH}$ standardization of milk before renneting could compensate for variations in milk. Such standardization would result in increased cheese consistency because it provides greater consistency in the rennet coagulation process, cutting of the curd, and acidification rates during cheesemaking, and coagulation temperature could be adjusted in tandem to achieve an appropriate $\Delta \mathrm{G}^{\prime} / \Delta \mathrm{t}$.

\section{Curd Microstructure}

Scanning Electron Microscopy. Scanning electron micrographs of curds $5 \mathrm{~min}$ after initiation of cutting are shown in Figure 3. For microstructural analysis, curd samples were collected after cutting, 3 min healing, and $1 \mathrm{~min}$ stirring. Micrographs shown are for gels of $4 \%$ protein set at $36^{\circ} \mathrm{C}$ (Figure $3 \mathrm{~A}, \mathrm{D}$, $\mathrm{G}$ ), of $6 \%$ protein set at $36^{\circ} \mathrm{C}$ (Figure $3 \mathrm{~B}, \mathrm{E}, \mathrm{H}$ ), and of $6 \%$ protein set at $28^{\circ} \mathrm{C}$ (Figure $3 \mathrm{C}, \mathrm{F}, \mathrm{I}$ ) at increasing nominal magnifications $(2,000,50,000$, and $100,000 \times)$. At lower magnification, curds set at $36^{\circ} \mathrm{C}$ and of $4 \%$ protein appeared to have a coarse protein network with regular voids, some of these containing small fat droplets (Figure 3A, white arrowhead), whereas curds set at $36^{\circ} \mathrm{C}$ at $6 \%$ protein appeared to have a dense casein network with void spaces filled with clusters of fat droplets (Figure 3B). Curds set at $28^{\circ} \mathrm{C}$ and with $6 \%$ protein appeared to have an even denser protein network, also interspersed with void spaces of varying sizes (Figure 3C). Medium- and high-magnification micrographs showed that casein micelles formed a continuous network in all treatments, but strands appeared thicker at higher temperature in both curds with 4 or $6 \%$ protein (Figure 3D, E) compared with curds coagulated at $28^{\circ} \mathrm{C}$ (Figure $3 \mathrm{~F}$ ). Casein micelles appeared smaller and less cross-linked in curds coagulated at low temperature compared with higher temperature (Figure 3I). This is consistent with the findings of Ong et al. (2011), who observed gels with a fine network when milk was set at $27^{\circ} \mathrm{C}$ compared with $36^{\circ} \mathrm{C}$. It is evident that the set temperature had a significant effect on formation of curd microstructure, and curds with $6 \%$ protein had a more dense protein network compared with curds with $4 \%$ protein. Ong et al. (2013) reported that curds that gelled at higher protein levels had a denser protein network compared with those from curds prepared with lower proteins levels; similar results were obtained in our study.
It should be considered that, in the present study, milk with $6 \%$ protein had a higher TS content (lower moisture) compared with milk with $4 \%$ protein (Table 2 ) and that, after cutting, curd samples set at $36^{\circ} \mathrm{C}$ with $4 \%$ protein, at $36^{\circ} \mathrm{C}$ with $6 \%$ protein, or at $28^{\circ} \mathrm{C}$ with $6 \%$ protein contained $81.8,77.6$, and $79.5 \mathrm{~g}$ of moisture/100 g of curd, respectively. These values, which differ from the standardized milk moisture content (Table 2), indicate that some syneresis occurred after cutting of the coagulum. The structural differences in curds from milk of $4 \%$ protein, with regular voids, could be partly due to a lower volume fraction of caseins, forming empty spaces that probably contained whey. Interestingly, fat globules were highly aggregated in the curds prepared from milk of protein $6 \%$ (Figure $3 \mathrm{~B}$ and $\mathrm{C}$ ). Fat in the standardized milk comes from whole milk and UF retentate. As the protein concentration is increased, the proportion of fat coming from UF also increases. In $4 \%$ protein milk, the proportion of fat from UF was approximately $33 \%$ ( $\sim 67 \%$ from whole milk), whereas in $6 \%$ milk the proportion of fat from UF retentate was approximately $71 \%(\sim 28 \%$ from whole milk). It is possible that the UF of whole milk has induced clustering of fat globules, which would be responsible for the aggregates observed in Figure 3B and C. Other investigators have also observed aggregated fat globules in gels prepared from concentrated milk (Ong et al., 2013). Fat globules of varying sizes were tightly entrapped in the protein network in curds with $28^{\circ} \mathrm{C}$ and $6 \%$ protein, whereas void spaces around fat globules were observed at $36^{\circ} \mathrm{C}$. This could be because of greater microsyneresis that occurred by rearrangement of the casein network at higher temperatures (van Vliet et al., 1991). This is also supported by the higher $\tan \delta_{40}$ values of the gels when set at higher temperature (Table 3) and is in agreement with the findings of van Vliet et al. (1991), who proposed that greater rearrangement of the casein network results in endogenous syneresis because of protein network contraction. Thus, formation of highly cross-linked casein micelles in curds coagulated at higher temperatures forms the structural basis for the increased gel-firming rate (Supplemental Figure S3, https://doi.org/10.3168/jds.2018-15039).

TEM. Figure 4 shows transmission electron micrographs, with increasing magnification, of curds prepared from milk of $4 \%$ protein set at $36^{\circ} \mathrm{C}$ (Figure $4 \mathrm{~A}$, $\mathrm{D}, \mathrm{G}), 6 \%$ protein set at $36^{\circ} \mathrm{C}$ (Figure $4 \mathrm{~B}, \mathrm{E}, \mathrm{H}$ ), and $6 \%$ protein set at $28^{\circ} \mathrm{C}$ (Figure $4 \mathrm{C}, \mathrm{F}, \mathrm{I}$ ). At low magnification, it was evident that casein micelles formed the protein network with interspersed fat globules. Milk with $6 \%$ protein had a dense casein network at both $36^{\circ} \mathrm{C}$ (Figure $4 \mathrm{~B}$ ) and $28^{\circ} \mathrm{C}$ (Figure $4 \mathrm{C}$ ). Milk with $4 \%$ protein set at $36^{\circ} \mathrm{C}$ appeared to have a less dense 

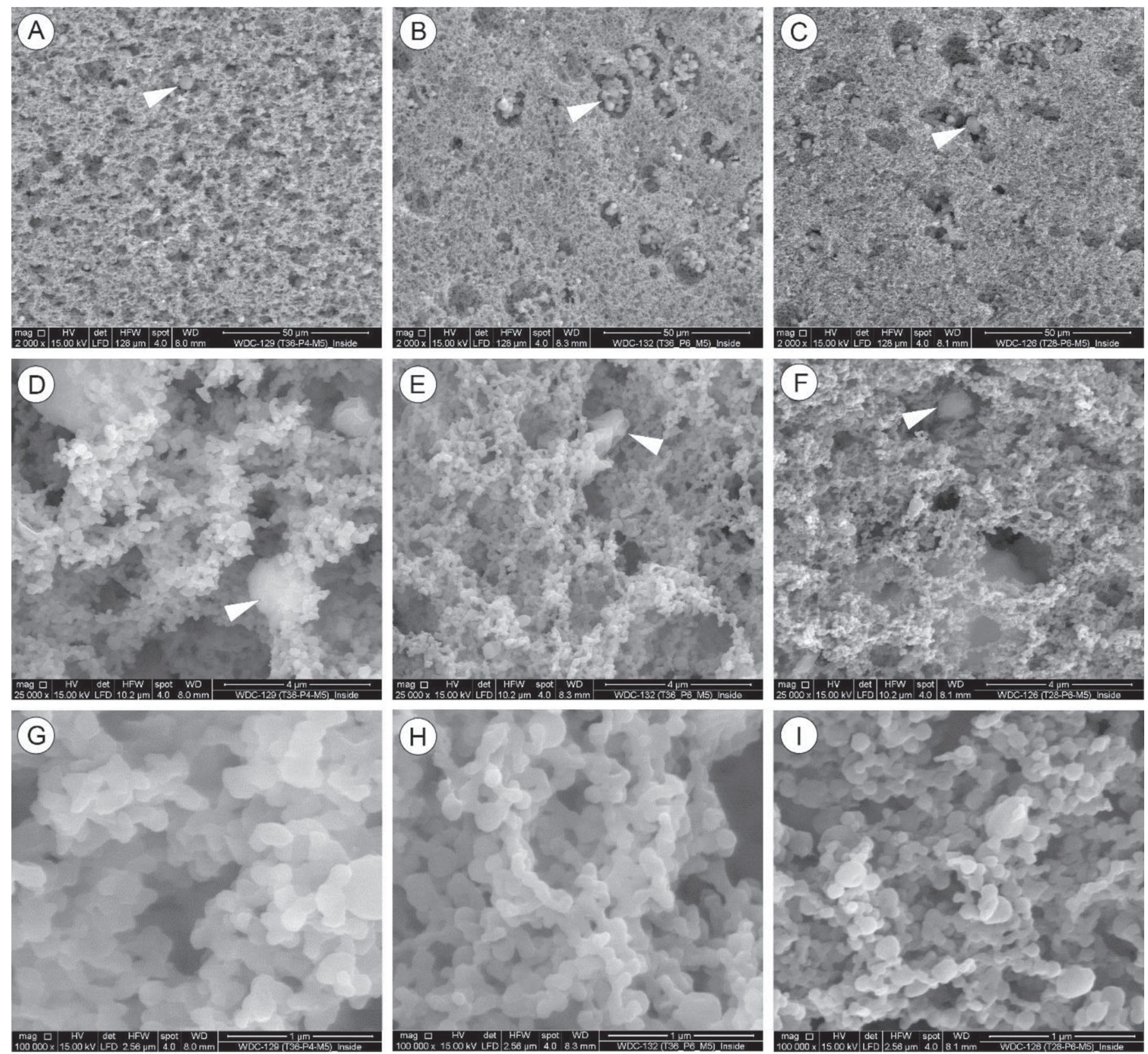

Figure 3. Internal microstructure of fractured curd particles prepared with milk of different protein concentrations and renneted at different set temperatures as analyzed by scanning electron microscopy. (A, D, G) $4 \%$ protein at $36^{\circ} \mathrm{C} .(\mathrm{B}, \mathrm{E}, \mathrm{H}) 6 \%$ protein at $36^{\circ} \mathrm{C}$. $(\mathrm{C}, \mathrm{F}, \mathrm{I}) 6 \%$ protein at $28^{\circ} \mathrm{C}$. Micrographs were taken at a distance of approximately $500 \mu \mathrm{m}$ from the outside of the particle. White arrowheads point to fat globules.

casein network with casein micelles forming localized aggregates, which were not always connected to each other within the plane of the section that was imaged (Figure 4A). At medium magnification, casein micelles were observed in localized aggregates (Figure 4D, E, F) for all treatments, but aggregates and casein micelles appeared smaller at $28^{\circ} \mathrm{C}$ (Figure $4 \mathrm{~F}$ ) compared with $36^{\circ} \mathrm{C}$ (Figure 4D and E). High-magnification images showed that the aggregates of casein micelles were indeed smaller, with fewer cross-links between micelles at $28^{\circ} \mathrm{C}$ (Figure $4 \mathrm{I}$ ) compared with $36^{\circ} \mathrm{C}$ regardless of protein levels (Figure $4 \mathrm{G}$ and $\mathrm{H}$ ). To summarize, at higher temperatures, extensive cross-linking between casein micelles occurred and thicker strands formed, making it difficult to discern individual casein micelles within aggregates. 

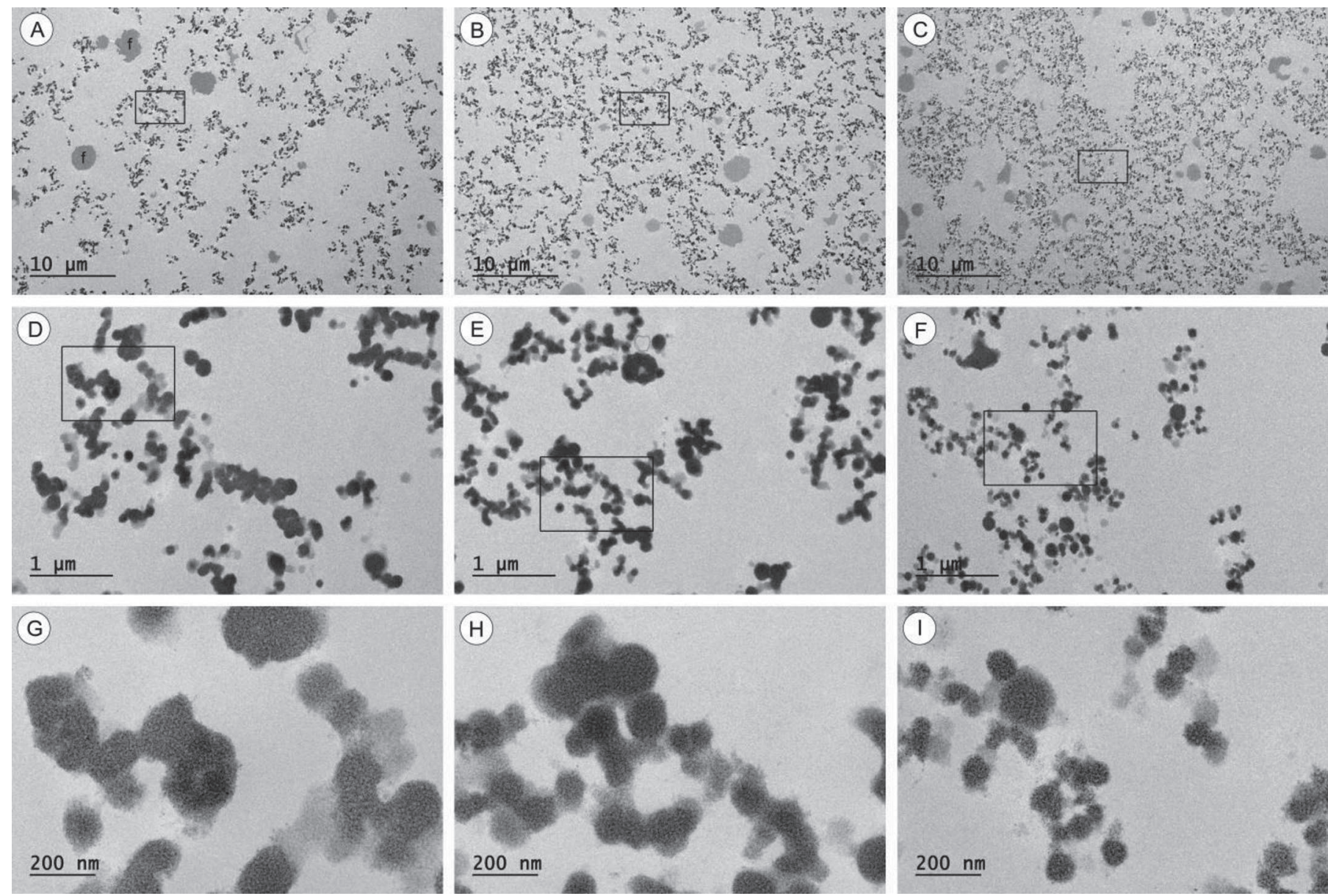

Figure 4. Internal microstructure of curd particles prepared with milk of different protein concentrations and renneted at different set temperatures as analyzed by transmission electron microscopy. (A, D, G) $4 \%$ protein at $36^{\circ} \mathrm{C}$. (B, E, H) $6 \%$ protein at $36^{\circ} \mathrm{C}$. $(\mathrm{C}, \mathrm{F}, \mathrm{I}) 6 \%$ protein at $28^{\circ} \mathrm{C}$. Micrographs were taken at a distance of approximately 500 to $600 \mu \mathrm{m}$ from the outside of the particle. Boxed areas are shown in increasing magnifications. $\mathrm{f}=$ fat globules.

The differences observed in curd microstructure using TEM parallel those observed with scanning electron microscopy (Figure 3), which indicated formation of bigger aggregates at $36^{\circ} \mathrm{C}$ compared with smaller and less cross-linked casein micelles at $28^{\circ} \mathrm{C}$. The TEM microstructure images further provide a mechanism for slow and fast curd formation in gels set at 28 and $36^{\circ} \mathrm{C}$, respectively (Figure 1A; Supplemental Figure S2, https://doi.org/10.3168/jds.2018-15039), because of differences in formation of aggregate size and casein micelles cross-linking. Interestingly, micelles with bigger aggregates and more cross-linking had more voids; this confirms the phenomenon of casein micelle rearrangement, which could possibly be due to bond relaxation at higher temperature that resulted in network rearrangement, causing endogenous syneresis. These results agree with those of Mellema et al. (2002), who proposed that gel strength is increased because of rear- rangement of the protein network, which increases at higher temperature. Muñoz et al. (2017) also observed rapid formation of bigger aggregates in gels prepared at $40^{\circ} \mathrm{C}$ compared with gels prepared at $30^{\circ} \mathrm{C}$.

As discussed above, gels set at lower temperatures had weaker casein micelle aggregates, producing curd with less capability to expel whey immediately after cutting compared with that at higher set temperatures. Less available whey during initial stirring can lead to greater curd breakage, causing fat and protein losses during downstream processing. Contradictory results have been reported with respect to fat losses at lower set temperature during cheesemaking (GovindasamyLucey et al., 2011; Ong et al., 2013), partly because of differences in curd microstructure as induced by the organization of casein aggregates within the network and thereby syneresis. This suggests that different coagulation temperatures associated with different cheese 
varieties (Table 1) will have an important influence on the curd cutting and syneresis behavior when using concentrated milk.

\section{CONCLUSIONS}

Application of UF to increase milk protein content for cheesemaking has various industrial benefits, such as reducing the effect of seasonal variation and increasing process efficiency. Increasing the protein concentration of milk to $6 \%$ resulted in faster development of curd firmness, which translates into a shorter CW. Although lowering of set temperature resulted in slower gel formation at all protein levels tested, higher protein concentration $(6 \%)$ at $28^{\circ} \mathrm{C}$ still produced excessively firmer coagula compared with milk with $4 \%$ protein set at $32^{\circ} \mathrm{C}$ (a condition close to standard cheesemaking practice). However, milk with a protein content of approximately $5 \%$ set at $28^{\circ} \mathrm{C}$ showed similar gel firmness, rate of gel formation, and $\mathrm{CW}$ compared with milk at $32^{\circ} \mathrm{C}$ with $4 \%$ protein. Based on observations from both scanning electron microscopy and TEM images of curd microstructure, we conclude that (1) lower set temperatures result in smaller casein aggregates with less crosslinked caseins compared with the highly aggregated casein structure in gels set at higher temperatures, and (2) such gels have a tendency for slow syneresis and expulsion of whey from within the gel network, as indicated by the $\tan \delta$ values observed. Further research is required to determine how this would influence losses of fat and protein that occur after cutting and stirring of curd during cheesemaking.

\section{ACKNOWLEDGMENTS}

The authors acknowledge the Dairy Levy Trust Fund administered by Dairy Research Ireland (Teagasc Walsh Fellowship) and Utah Agriculture Experiment Station (Utah State University, Logan) for providing funds for this research. We thank the Electron Microscopy Core Research Facility and the NanoScale Imaging and Surface Analysis Lab at the University of Utah (Salt Lake City) for use of the transmission and scanning electron microscope, respectively. We are also grateful to Leprino Foods Company (Denver, $\mathrm{CO}$ ) for supporting the Biostructure Center, part of the Western Dairy Center at Utah State University.

\section{REFERENCES}

Acharya, M. R., and V. V. Mistry. 2004. Comparision of effect of vacuum-condensed and ultrafiltered milk on Cheddar cheese. J. Dairy Sci. 87:4004-4012. https://doi.org/10.3168/jds.S0022 $-0302(04) 73541-9$
Broome, M. C., S. E. Tan, M. A. Alexander, and B. Manser. 1998 Low-concentration-ratio ultrafiltration for Cheddar cheese manufacture. Aust. J. Dairy Technol. 53:5-10.

Francolino, S., F. Locci, R. Ghiglietti, R. Iezzi, and G. Mucchetti 2010. Use of milk protein concentrate to standardize milk composition in Italian citric Mozzarella cheese making. Lebensm. Wiss. Technol. 43:310-314. https://doi.org/10.1016/j.lwt.2009.08.007.

Gavlak, R., D. Horneck, and R. O. Miller. 2005. Phosphorus, potassium, sulfur, calcium, magnesium, sodium, zinc, manganese, copper, iron, and molybdenum of botanical materials. Pages 167-169 in Soil, Plant and Water Reference Methods for the Western Region. 3rd ed. WCC-103 Publication, Colorado State University, Fort Collins, $\mathrm{CO}$

Govindasamy-Lucey, S., J. J. Jaeggi, A. L. Bostley, M. E. Johnson, and J. A. Lucey. 2004. Standardization of milk using cold ultrafiltration retentates for the manufacture of Parmesan cheese. J. Dairy Sci. 87:2789-2799. https://doi.org/10.3168/jds.S0022 -0302(04)73406-2.

Govindasamy-Lucey, S., J. J. Jaeggi, M. E. Johnson, T. Wang, and J. A. Lucey. 2005. Use of cold ultrafiltered retentates for standardization of milks for pizza cheese: Impact on yield and functionality. Int. Dairy J. 15:941-955. https://doi.org/10.1016/j.idairyj.2004.08 .017 .

Govindasamy-Lucey, S., J. J. Jaeggi, C. Martinelli, M. E. Johnson, and J. A. Lucey. 2011. Standardization of milk using cold ultrafiltration retentates for the manufacture of Swiss cheese: Effect of altering coagulation conditions on yield and cheese quality. J Dairy Sci. 94:2719-2730. https://doi.org/10.3168/jds.2010-3842.

Guinee, T. P. D. J. O'Callaghan, E. O. Mulholland, and D. Harrington. 1996a. Milk protein standardization by ultrafiltration for Cheddar cheese manufacture. J. Dairy Res. 63:281-293. https:// doi.org/10.1017/S0022029900031770.

Guinee, T. P., D. J. O'Callaghan, P. D. Pudja, and N. O'Brien. 1996b. Rennet coagulation properties of retentates obtained by ultrafiltration of skim milks heated to different temperatures. Int. Dairy J. 6:581-596. https://doi.org/10.1016/0958-6946(95)00061-5.

Guinee, T. P., B. T. O'Kennedy, and P. M. Kelly. 2006. Effect of milk protein standardization using different methods on the composition and yields of Cheddar cheese. J. Dairy Sci. 89:468-482. https: //doi.org/10.3168/jds.S0022-0302(06)72110-5.

Guinee, T. P., P. D. Pudja, and E. O. Mulholland. 1994. Effect of milk protein standardization, by ultrafiltration, on the manufacture, composition and maturation of Cheddar cheese. J. Dairy Res. 61:117-131. https://doi.org/10.1017/S0022029900028119.

Heino, A. J. Uusi-Rauva, and M. Outinen. 2010. Pre-treatment methods of Edam cheese milk. Effect on cheese yield and quality. Lebensm. Wiss. Technol. 43:640-646. https://doi.org/10.1016/j.lwt 2009.11.004

Horne, D. S. 1998. Casein interactions: Casting light on the black boxes, the structure in dairy products. Int. Dairy J. 8:171-177. https://doi.org/10.1016/S0958-6946(98)00040-5.

Horne, D. S., and J. M. Banks. 2004. Rennet-induced coagulation of milk. Pages 47-70 in Cheese: Chemistry, Physics, and Microbiology. Vol. 1 General Aspects. 3rd ed. P. F. Fox, T. M. Cogan, T. Guinee, and P. L. H. McSweeney, ed. Elsevier Applied Science, Amsterdam, the Netherlands.

Hussain, I., A. S. Grandison, and A. E. Bell. 2012. Effects of gelation temperature on Mozzarella-type curd made from buffalo and cows milk. 1: Rheology and microstructure. Food Chem. 134:1500-1508. https://doi.org/10.1016/j.foodchem.2012.03.062.

Karlsson, A. O., R. Ipsen, and Y. Ardö. 2007. Rheological properties and microstructure during rennet induced coagulation of UF concentrated skim milk. Int. Dairy J. 17:674-682. https://doi.org/10 .1016/j.idairyj.2006.08.002.

Liu, D. Z., M. G. Weeks, D. E. Dunstan, and G. J. O. Martin. 2014 Alterations to the composition of casein micelles and retentate serum during ultrafiltration of skim milk at 10 and $40{ }^{\circ} \mathrm{C}$. Int. Dairy J. 35:63-69. https://doi.org/10.1016/j.idairyj.2013.10.017.

Lu, Y., D. J. McMahon, L. E. Metzger, A. Kommineni, and A. H. Vollmer. 2015. Solubilization of rehydrated frozen highly concen- 
trated micellar casein for use in liquid food applications. J. Dairy Sci. 98:5917-5930. https://doi.org/10.3168/jds.2015-9482.

Lu, Y., D. J. McMahon, and A. H. Vollmer. 2016. Investigating cold gelation properties of recombined highly concentrated micellar casein concentrate and cream for use in cheese making. J. Dairy Sci. 99:5132-5143. https://doi.org/10.3168/jds.2015-10791.

Lu, Y., D. J. McMahon, and A. H. Vollmer. 2017. Investigating rennet coagulation properties of recombined highly concentrated micellar casein concentrate and cream for use in cheese making. J. Dairy Sci. 100:892-900. https://doi.org/10.3168/jds.2016-11648.

Maciel, G. de M., M. Hammershøj, P. D. Frederiksen, J. Sørensen, M. Bakman, N. A. Poulsen, and L. B. Larsen. 2015. Dairy processing and cold storage affect the milk coagulation properties in relation to cheese production. Dairy Sci. Technol. 95:101-114. https://doi .org/10.1007/s13594-014-0202-5.

McMahon, D. J., and R. Brown. 1982. Evaluation of farmograph for comparing rennet solutions. J. Dairy Sci. 65:1639-1642.

Mellema, M., P. Walstra, J. H. J. Van Opheusden, and T. Van Vliet. 2002. Effects of structural rearrangements on the rheology of rennet-induced casein particle gels. Adv. Colloid Interface Sci. 98:2550. https://doi.org/10.1016/S0001-8686(01)00089-6.

Mishra, R., S. Govindasamy-Lucey, and J. A. Lucey. 2005. Rheological properties of rennet-induced gels during the coagulation and cutting process: Impact of processing conditions. J. Texture Stud. 36:190-212. https://doi.org/10.1111/j.1745-4603.2005.00011.x.

Mistry, V. V., and J. L. Maubois. 2017. Application of membrane separation technology to cheese production. Pages 677-697 in Cheese: Chemistry, Physics, and Microbiology. Vol. 2: Cheese Technology and Major Cheese Groups. P. L. H. McSweeney, P. F. Fox, P. D. Cotter, and D. W. Everett, ed. Academic Press, San Diego, CA.

Muñoz, S. V., M. G. Torres, F. Q. Guerrero, and R. R. Talavera. 2017. A new study of the kinetics of curd production in the process of cheese manufacture. J. Dairy Res. 84:479-483. https://doi.org/10 1017/S002202991700053X.

Nájera, A. I., M. de Renobales, and L. J. R. Barron. 2003. Effects of $\mathrm{pH}$, temperature, $\mathrm{CaCl}_{2}$ and enzyme concentrations on the rennetclotting properties of milk: A multifactorial study. Food Chem. 80:345-352. https://doi.org/10.1016/S0308-8146(02)00270-4.

O'Callaghan, T. F., D. Hennessy, S. McAuliffe, K. N. Kilcawley, M. O'Donovan, P. Dillon, R. P. Ross, and C. Stanton. 2016. Effect of pasture versus indoor feeding systems on raw milk composition and quality over an entire lactation. J. Dairy Sci. 99:9424-9440. https://doi.org/10.3168/jds.2016-10985.

Ong, L., R. R. Dagastine, M. A. E. Auty, S. E. Kentish, and S. L. Gras. 2011. Coagulation temperature affects the microstructure and composition of full fat cheddar cheese. Dairy Sci. Technol 91:739-751. https://doi.org/10.1007/s13594-011-0033-6.

Ong, L., R. R. Dagastine, S. E. Kentish, and S. L. Gras. 2013. Microstructure and composition of full fat Cheddar cheese made with ultrafiltered milk retentate. Foods 2:310-331. https://doi.org/10 $.3390 /$ foods 2030310 .

Oommen, B. S., V. Mistry, and M. G. Nair. 2000. Effect of homogenization of cream on composition, yield, and functionality of Cheddar cheese made from milk supplemented with ultrafiltered milk. Lait 80:77-91. https://doi.org/10.1051/lait:200010.

Ozturk, M. S. Govindasamy-Lucey, J. J. Jaeggi, M. E. Johnson, and J. A. Lucey. 2015. Low-sodium Cheddar cheese: Effect of fortification of cheese milk with ultrafiltration retentate and high-hydrostatic pressure treatment of cheese. J. Dairy Sci. 98:6713-6726. https://doi.org/10.3168/jds.2015-9549.

Pouliot, Y. 2008. Membrane processes in dairy technology-From a simple idea to worldwide panacea. Int. Dairy J. 18:735-740.

Qvist, K. B. 1979. Reestablishment of the original rennetability of milk after cooling. 1. The effect of cooling and LTST pasteurization of milk and renneting. Milchwissenschaft 34:467-470.

Salvatore, E., A. Pirisi, and M. Corredig. 2011. Gelation properties of casein micelles during combined renneting and bacterial fermentation: Effect of concentration by ultrafiltration. Int. Dairy J. 21:848-856. https://doi.org/10.1016/j.idairyj.2011.05.006.

Sandra, S., C. Cooper, M. Alexander, and M. Corredig. 2011. Coagulation properties of ultrafiltered milk retentates measured using rheology and diffusing wave spectroscopy. Food Res. Int. 44:951-956. https://doi.org/10.1016/j.foodres.2011.02.018.

Upreti, P., V. V. Mistry, and M. R. Acharya. 2011. Characterization of rennet coagulation of milk concentrated by vacuum condensing and ultrafiltration. Dairy Sci. Technol. 91:383-395. https://doi .org/10.1007/s13594-011-0004-y.

van Vliet, T., H. J. M. van Dijk, P. Zoon, and P. Walstra. 1991. Relation between syneresis and rheological properties of particle gels. Colloid Polym. Sci. 269:620-627.

van Vliet, T., and P. Walstra. 1994. Water in casein gels; How to get it out or keep it in. J. Food Eng. 22:75-88. https://doi.org/10.1016/ 0260-8774(94)90026-4.

Waungana, A., H. Singh, and R. J. Bennett. 1998. Rennet coagulation properties of skim milk concentrated by ultrafiltration: Effects of heat treatment and $\mathrm{pH}$ adjustment. Food Res. Int. 31:645-651. https://doi.org/10.1016/S0963-9969(99)00038-1. 